\title{
PENGEMBANGAN MEDIA PEMBELAJARAN PERMAINAN JENGA MODIFIKASI UNTUK MATERI IPA MACAM-MACAM GAYA DAN PEMANFAATANNYA KELAS IV SDN LENTENG AGUNG 03
}

\author{
Nike Tri Astuti \\ Universitas Negeri Jakarta \\ nike.triastuti@gmail.com
}

\begin{abstract}
Abstrak
Penelitian yang dilakukan bertujuan untuk menghasilkan produk berupa media permainan Jenga Edukasi untuk materi IPA (Ilmu Pengetahuan Alam) Macammacam Gaya dan Pemanfaatannya di kelas IV SD. Media permainan Jenga Edukasi ini mengacu pada Tema 7 "Indahnya Keragaman di Negeriku" Kurikulum 2013. Penelitian ini menggunakan metode penelitian dan pengembangan atau Research and Development $(\mathrm{R} \& \mathrm{D})$ dengan menggunakan model pengembangan ADDIE. Produk divalidasi keefektifannya oleh ahli bahasa, ahli materi, ahli media, dan guru kelas IV SD. Hasil dari validasi tersebut, media permainan Jenga Edukasi memperoleh penilaian akhir 97,3\%. Media diuji coba hanya sampai tahap one to one dikarenakan pandemi covid-19 yang melibatkan lima siswa kelas IV. Hasil dari uji coba tersebut memperoleh $94 \%$. Berdasarkan pengujian keefektifan produk yang telah dilaksanakan, media permainan Jenga Edukasi dinyatakan sangat layak untuk digunakan pada pembelajaran IPA materi Macam-macam Gaya dan pemanfaatannya di kelas IV SD. Media inovatif dan kreatif yang dikembangkan oleh peneliti menjadikan siswa semangat dan termotivasi pada saat penemuan konsep melalui aktivitas proses serta dapat digunakan guru sebagai media penunjang pembelajaran yang lebih optimal, sehingga pengaruh terhadap hasil belajar yang digapai akan lebih memuaskan.
\end{abstract}

Kata Kunci: Permainan, Jenga, Gaya dan Pemanfaatannya

\section{Abstract}

Research was aims to produce a product of the Jenga game of media education for Science material for the various force and utilization at IV grade. This educational media game refers to the 7th theme "the beauty of diversity in my country" curriculum 2013. The study employs the method of research and development (R\&D) with ADDIE development models. Products are validated with their effectiveness by linguists, materials experts, media experts, and IV grade teachers. The result of the validation is that the media education jenga has a final rating of 97.3\%. The media tested only until stage one to one because of the covid-19 pandemic, which involved five grade iv students. the results of the trial obtained 94\%. Based on testing effectiveness of the product, the Jenga game of media education is declared very worthy to be used for Science material for the various force and utilization at IV grade. 
The innovative and creative media developed by researchers makes students enthusiastic and motivated at the time of conceptual discovery through process activity and can be used by teachers as more optimal teaching learning support media, so that the impact of learning it can accomplish will be more gratify

Keywords: Game, Jenga, Various force and uses

\section{PENDAHULUAN}

Pendidikan merupakan salah satu modal dalam pembangunan suatu bangsa, maka penting untuk bangsa dapat menyelenggarakan pendidikan formal yang terstruktur dan berjenjang. UU Nomor 20 tahun 2003 menjelaskan bahwa pendidikan merupakan cara atau upaya yang dilakukan secara terencana agar peserta didik aktif dalam proses pembelajaran dalam mengembangkan potensi dirinya dalam berbagai bidang sehingga mampu dimanfaatkan bagi dirinya, masyarakat, bangsa, dan negara.

Periode perkembangan anak usia Sekolah Dasar rata-rata tergolong dalam periode operasional konkret (7 tahun - 11 tahun) yang ditandai dengan pemikiran yang mulai berkembang, penalaran yang semakin logis melalui peristiwa konkret dan mampu mengklasifikasikan ke dalam bentuk yang berbeda (Piaget, 2016). Maka penggunaan gaya mengajar, model serta media pembelajaran akan mempengaruhi perkembangan anak. Proses pembelajaran di sekolah, guru dan siswa menjadi model penting dalam pelaksanaan pembelajaran di sekolah. Keberhasilan suatu pembelajaran dalam kelas sangat dipengaruhi oleh kualitas dan kemampuan guru dalam mengelola kelas.

Pembelajaran kurikulum 2013 seyogyanya mampu membuat guru semakin kreatif dalam mengelola serta meningkatkan kemampuan dalam mengolah media dalam kelas. Pembelajaran dirancang dengan siswa sebagai subjek belajar, sedangkan guru hanya sebagai fasilitator dan salah satu sumber belajar bagi siswa. Media dapat didefinisikan sebagai alat yang digunakan untuk berinteraksi antara guru dengan siswa agar selama proses pembelajaran berlangsung dapat berjalan dengan lancar (Karimah, 2020). Media dengan ketepatan isi dan tujuan pembelajaran akan dapat menjadi bahan pembelajaran efektif untuk merangsang minat dan perhatian peserta didik sehingga mampu berjalan efektif untuk mencapai tujuan pembelajaran. Pendidikan di Sekolah Dasar memuat beberapa mata pelajaran, dan salah satu mata pelajaran yang melibatkan agar siswa aktif adalah Ilmu Pengetahuan Alam (IPA).

IPA menurut Departemen Pendidikan Nasional menyatakan bahwa IPA berhubungan dengan cara mencari tahu tentang alam secara sistematis, dan bukan hanya penguasaan kumpulan pengetahuan yang berupa fakta-fakta tetapi disertai dengan konsepkonsep, prinsip, prinsip yang merupakan suatu penemuan (Depdiknas, 2006). Pembelajaran IPA lebih sering dilaksanakan melalui praktikum atau pengalaman belajar 
langsung daripada teori karena berkaitan dengan ilmu alam dan sekitarnya. Penerapan pembelajaran IPA akan lebih bermakna dan akan lebih mudah dipahami ketika siswa belajar sambil melakukan (learning by doing) atau dengan memanfaatkan media menyenangkan yang mendorong siswa menjadi aktif dalam pengalaman pelaksanaan pembelajaran secara langsung. Namun, masih sering ditemui pada pembelajaran IPA guru masih memposisikan diri sebagai subjek yang mengakibatkan perkembangan potensi kritis (chritical thinking) dan kreativitas (creativity) siswa dalam menggunakan konsep untuk memecahkan masalah melalui aktivitas proses pembelajaran kurang optimal.

Berdasarkan hasil observasi yang dilakukan peneliti, guru dan siswa mengharapkan mampu mengembangkan proses belajar menyenangkan dalam kelas dan kerjasama dengan teman melalui kegiatan fisik serta menyimpulkan hasil bersama yang mampu membangun sikap ingin tahu dan pengetahuan baru. Analisis tersebut peneliti menyimpulkan bahwa dalam menanamkan materi diperlukan media pembelajaran berbasis permainan melalui aktifitas fisik yang mampu mengatasi permasalahan yang dialami oleh siswa.

Pentingnya penggunaan media dalam pembelajaran selain tujuan, materi, metode, dan evaluasi dianggap menjadi peran dalam keberhasilan suatu pembelajaran. Media yang digunakan terdapat berbagai klasifikasi untuk aktivitas pembelajaran yang terdiri dari: media cetak, media grafis dan media pameran, media audio, gambar bergerak, dan multimedia (Heinich,dkk, 2017). Berdasarkan klasifikasi tersebut, media yang peneliti kembangkan termasuk ke dalam media pameran. Permainan merupakan suatu aktivitas yang menggembirakan dan menyenangkan untuk memperoleh keterampilan tertentu (Soepomo, 2017). Peneliti berinovasi untuk menciptakan permainan jenga edukasi yang diharapkan mampu menjadi wadah konstruksi informasi anak sehingga dapat menciptakan perubahan suasana dalam sikap dan tingkah laku anak. Peneliti melakukan pengembangan permainan jenga merupakan langkah tepat dalam menciptakan pembelajaran sambil bermain karena permainan ini sudah pernah dimainkan dalam kelas tersebut, sehingga peneliti menyesuaikan permainan tersebut dengan karakteristik dan tujuan pembelajaran. Jenga diciptakan tahun 1970-an oleh Leslie Scott seorang pendiri Oxford Games. Jenga merupakan permainan keahlian mengambil balok dalam susunan kemudian diletakkan kembali pada tumpukan balok paling atas dengan tetap menjaga keseimbangan susunan balok. Pemain hanya perlu mengambil satu demi satu balok yang terdapat dalam tumpukan dan meletakkannya diatas tower tanpa membuat tumpukan terjatuh (Sholihah, 2020).

Perkembangan karakteristik siswa kelas IV yang cenderung senang bermain dan melakukan aktivitas fisik menjadi landasan utama peneliti dalam mengembangkan permainan jenga edukasi. Pembelajaran yang hanya mendengarkan penjelasan guru serta hanya melalui video pembelajaran membuat siswa cenderung bosan. Pengembangan media permainan jenga edukasi merupakan salah satu usaha kreatif dan inovatif guna menghasilkan produk untuk menyampaikan pesan atau materi melalui media perantara permainan dengan menyenangkan dan efektif. 
Observasi yang dilakukan peneliti melalui pengamatan dan wawancara di kelas IV SDN Lenteng Agung 03 bahwa dalam kelas, guru kurang dalam memaksimalkan suasana belajar yang aktif, kurang adanya komunikasi dua arah antara guru dengan siswa. Guru hanya memanfaatkan media tambahan berupa video pembelajaran dari internet dan guru belum pernah memaksimalkan media yang menyenangkan dalam kelas melalui proses belajar dan berpikir tentang diri sendiri serta lingkungan. Siswa akan semakin mudah memahami konsep apabila melakukan eksperimen serta berkolaborasi untuk menyimpulkan penemuan mereka.

Muatan pembelajaran IPA, terdapat berbagai materi dengan tingkat kesukaran dan kepadatan yang berbeda-beda, berdasarkan observasi yang dilakukan peneliti, materi yang dirasa cukup padat dan memerlukan media pembelajaran yang menyenangkan dalam pengimplementasiannya adalah materi macam-macam gaya dan pemanfaatannya. Kesulitan yang dihadapi guru pada saat materi ini ialah kurang inovasi yang dilakukan guru untuk melakukan praktik atau kegiatan dalam kelas, padahal kelas IV SD cenderung ingin tahu dan senang melakukan praktik. Pemindahan pemahaman yang hanya melalui lisan tidak mampu mengembangkan Chritical Thinking siswa. Pandangan tersebut diperkuat dengan hasil wawancara peneliti kepada 5 siswa kelas IV yang menyatakan kurang paham bahkan kurang suka dengan materi tersebut dikarenakan banyaknya macam gaya namun tidak disampaikan secara tepat dengan hanya melalui video dan penyampaian penjelasan dari guru. Gejala yang dialami siswa adalah sedikitnya materi yang mereka ingat setelah proses pembelajaran selesai sehingga hal tersebut dikhawatirkan akan mempengaruhi hasil belajar dari pengambilan nilai yang dilakukan oleh guru. Apalagi usia kelas IV berada pada tatanan usia bermain sehingga guru dituntut untuk membuat kelas mampu melakukan aktivitas nyata sehingga pembelajaran yang sulit pun mampu tersalurkan dan dapat dimanfaatkan oleh siswa.

Harapan siswa dan guru yang disampaikan melalui kuisioner yang disebar peneliti ialah mampu mengembangkan proses belajar menyenangkan dalam kelas dan kerjasama dengan teman melalui kegiatan fisik serta menyimpulkan hasil bersama yang mampu membangun sikap ingin tahu dan pengetahuan baru akan lebih diingat siswa dengan adanya pembuktian gaya yang langsung dilaksanakan. Sehingga dari analisis tersebut dapat disimpulkan bahwa dalam menanamkan pembelajaran macam-macam gaya dan pemanfaatannya diperlukan media pembelajaran berbasis permainan melalui aktifitas fisik yang mampu mengatasi permasalahan yang dialami oleh siswa.

Keresahan yang dirasakan membuat peneliti berinovasi untuk mengembangkan permainan jenga edukasi mengenai materi macam-macam gaya dan pemanfaatannya yang berguna juga untuk meningkatkan kepercayaan diri dalam bersosialisasi dan menemukan konsep bersama sehingga timbullah karakter mandiri. Permainan jenga juga disarankan oleh guru kelas IV SDN Lenteng Agung 03 karena sudah pernah dipraktikkan sebagai selingan pada saat pembelajaran yang membuat siswa menjadi lebih aktif dan semangat 
serta dirasa permainan yang akan dikembangkan ini sesuai dengan tahap perkembangan konkret anak dalam menerima materi yang didasarkan dengan pemikiran serta pengalaman awal melalui instruksi yang diberikan pada permainan Jenga Edukasi untuk dapat berfikir secara logis dan nyata membuat siswa merasa tertantang untuk memainkannya.

Upaya untuk mewujudkan tujuan pembelajaran ditunjang dengan media yang menyenangkan sesuai dengan materi dan karakteristik anak yang menyukai metode belajar sambil bermain. Media permainan Jenga Edukasi tergolong media baru dan belum banyak yang mendesain pembelajaran dengan media permainan Jenga Edukasi, jadi besar kemungkinan bahwa media yang dibawakan dalam materi ini akan mendapat antusiasme siswa kelas IV yang positif, didasarkan pada kecenderungan siswa yang masih berada pada tataran usia bermain.

Penyempurnaan permainan jenga edukasi, peneliti melengkapi permainan ini dengan kartu instruksi sesuai dengan materi gaya yang tertuang dalam Kompetensi Dasar buku Tematik SD Kelas IV. Instruksi tersebut akan memanfaatkan lingkungan sekitar dan juga balok itu sendiri sehingga memunculkan kreativitas siswa dalam memecahkan masalah sehingga mampu menghidupkan kelas melalui aktivitas proses pembelajaran untuk meningkatkan potensi siswa terkhususkan pada materi macam-macam gaya dan pemanfaatannya. Kartu aktivitas akan dibedakan menjadi lima warna kartu yang akan mewakili satu jenis gaya setiap warna serta komposisi balok ialah 36 balok yang akan diberi warna menggunakan cat kayu, 1 dadu, dan panduan permainan. Kartu aktivitas berisikan aktivitas proses pembelajaran dalam mendapatkan produk atau materi macammacam gaya dan pemanfaatannya melalui instruksi gambar dan tulisan. Balok jenga berfungsi sebagai penentu dalam dalam melaksanakan instruksi yang terdapat pada kartu yang diambil oleh pemenang. Setiap pemain akan mendapatkan reward berupa poin apabila berhasil melakukan aktivitas proses yang ditentukan dalam kartu serta mendapatkan punishment apabila mengalami kekalahan.

Berdasarkan uraian yang telah dipaparkan, maka peneliti akan melakukan pengembangan permainan jenga edukasi di kelas IV SD dengan judul penelitian "Pengembangan Media Pembelajaran Permainan Jenga Modifikasi untuk Materi IPA Macam-macam Gaya dan Pemanfaatannya Kelas IV SD”.

\section{METODE PENELITIAN}

Penelitian bertujuan untuk menghasilkan produk berupa permainan Jenga Edukasi pada pembelajaran IPA kelas IV dengan materi yang akan dibahas yaitu Tema 7 "Indahnya Keragaman di Negeriku" dengan materi Macam-macam Gaya dan Pemanfaatannya yang mengacu pada Buku Tematik Terpadu Kurikulum 2013. Permainan Jenga Edukasi dalam posisinya mampu membantu guru sebagai fasilitator dalam membimbing peserta didik khususnya materi gaya dan pemanfaatannya. Permainan ini akan dilakukan melalui 
aktivitas proses belajar dalam mencapai pemahaman dan penguasaan materi gaya dan pemanfaatannya dengan subjek penelitian kelas IV.

Penelitian ini menggunakan metode penelitian dan pengembangan atau Research and Development (R\&D) yang memiliki pengertian ialah usaha untuk mengembangkan dan memvalidasi produk-produk yang akan digunakan dalam Pendidikan (Borg \& Gall, 2013). Peneliti menggunakan model pengembangan ADDIE yang merupakan singkatan dari Analyze (analisis), Design (perancangan), Development (pengembangan), Implementation (implementasi), dan Evaluation (evaluasi). Tahap kegiatan dalam model ADDIE pada dasarnya memiliki kaitan satu sama lain dengan urutan yang terprogramkan menjadi sistematis dalam upaya pemecahan masalah belajar sesuai dengan kebutuhan dan karakteristik peserta didik. Oleh karena itu, penggunaan model ini perlu dilakukan secara bertahap dan juga menyeluruh. Uji coba ahli (expert review) yang terdiri dari ahli bahasa, ahli materi, ahli media, dan guru kelas IV akan dilakukan sebelum akhirnya media permainan Jenga Edukasi diterjunkan langsung kepada siswa untuk digunakan dalam kelas.

Penggunaan metode pengumpulan data untuk kebutuhan analisis, peneliti melakukan observasi, wawancara, dan kuisioner kepada guru dan siswa yang bertujuan untuk memperoleh data atau informasi yang diperlukan dalam penelitian. Teknik analisis data bagi para ahli menggunakan Rating Scale yaitu penilaian yang didasarkan pada suatu skala tertentu dari rendah sampai tinggi untuk menunjukkan kelayakan produk yang telah dikembangkan oleh peneliti.

Tabel 1. Penilaian Rating Scale

\begin{tabular}{|c|c|c|}
\hline Deskripsi & Skor & Huruf \\
\hline Sangat Baik & 4 & A \\
\hline Baik & 3 & B \\
\hline Cukup Baik & 2 & C \\
\hline Kurang Baik & 1 & D \\
\hline
\end{tabular}

Setelah data diperoleh dari validator, kemudian peneliti melakukan perhitungan terhadap hasil kuisioner untuk mengetahui kualitas media permainan Jenga Edukasi. Penilaian evaluasi one by one menggunakan skala Guttman dimana skala pengukuran jawaban "Ya" bernilai 1 dan "Tidak" bernilai 0 .

$$
\text { Rata-rata }=\frac{\text { jumlah skor hasil pengumpulan data }}{\text { jumlah indikator yang dinilai }} \times 100 \%
$$


Setelah mendapatkan hasil peneliti mengkonversi data kualitatif menjadi data kuantitatif untuk menentukan kualitas dan kelayakan produk terhadap evaluasi yang diperoleh.

Tabel 2. Tabel Rentang Skor

\begin{tabular}{|c|c|}
\hline Skor & Deskripsi \\
\hline $0 \%-25 \%$ & Kurang Baik \\
\hline $26 \%-50 \%$ & Cukup Baik \\
\hline $51 \%-75 \%$ & Baik \\
\hline $76 \%-100 \%$ & Sangat Baik \\
\hline
\end{tabular}

Media Permainan Jenga Edukasi dikatakan layak diaplikasikan apabila mencapai skor diatas $76 \%$ dengan kualitas sangat baik berdasarkan pada seluruh saran dalam menilai media permainan Jenga Edukasi untuk Materi IPA Macam-macam Gaya dan Pemanfaatannya.

\section{HASIL PENELITIAN DAN PEMBAHASAN}

Media Permainan Jenga Edukasi dikembangkan dengan menggunakan model pengembangan ADDIE yaitu: analyze, design, development, implementation, dan evaluation. Berikut ini pemaparan hasil pengembangan yang dilakukan peneliti di setiap tahap.

1. Tahap Analisis (Analyze)

Peneliti melakukan analisis kebutuhan melalui observasi pada saat kegiatan belajar mengajar serta wawancara kepada guru dan siswa kelas IV SDN Lenteng Agung 03. Observasi dilakukan secara dalam jaringan (daring) disebabkan oleh pandemi covid-19 pada bulan Agustus-Oktober 2020 bersamaan ketika peneliti melaksanakan Praktik Keterampilan Mengajar (PKM). Pada saat pembelajaran macam-macam gaya dan pemanfaatannya, guru hanya menggunakan video dari internet sehingga penanaman konsep IPA kurang maksimal dan materi banyak mengadopsi dari kehidupan sehari-hari, namun siswa kesulitan dalam memahami materi tersebut karena salah satu faktornya adalah siswa hanya mendengar dan tidak melakukan komunikasi dua arah. Ketika kelas sudah mulai tidak kondusif, guru memberikan permainan untuk mengembalikan fokus siswa. Karakteristik siswa kelas IV cenderung berada pada masa bermain yang aktif dan kreatif, melibatkan objek konkret sebagai pengalaman nyata dalam memahami konsep. Guru serta siswa kelas IV mengharapkan peneliti mampu mengembangkan media pembelajaran sambil bermain yang mampu dilaksanakan secara langsung.

2. Tahap Perencanaan (Design)

Peneliti kemudian menentukan tujuan yang ingin dicapai dalam pengembangan dengan fokus kepada analisis materi pembelajaran, tujuan pembelajaran, dan pemilihan 
media. Peneliti merancang materi dan produk yang dikembangkan serta menyusun instrumen penilaian kualitas. Literatur pada buku kelas IV Kurikulum 2013 Tema 7 "Indahnya Keragaman di Negeriku" mengenai macam-macam gaya dan pemanfaatannya. Peneliti juga merancang materi dan produk yang dikembangkan berupa kerangka desain media permainan Jenga Edukasi serta menyusun instrumen penilaian kualitas media.

3. Tahap Pengembangan (Develop)

Peneliti fokus untuk menghasilkan dan memvalidasi media yang dikembangkan. Setelah produk telah terealisasikan, maka dilakukan expert review. Hasil dari evaluasi tersebut dapat digunakan sebagai dasar untuk melakukan analisis dan revisi terhadap media yang dikembangkan dan sebagai dasar untuk melakukan uji coba kepada siswa.

\section{Tahap Implementasi (Implement)}

Setelah melakukan penyempurnaan produk berdasarkan saran dan masukan validator, maka produk siap untuk diuji coba kepada siswa. Media akan diuji coba kepada peserta didik hanya sampai tahap one to one dan tidak melewati tahap small group dan field test dikarenakan adanya pandemi covid-19 dengan subjek peneliti yaitu kelas IV.

5. Evaluasi (Evaluate)

Teknik evaluasi yang digunakan dalam penelitian ini ialah evaluasi formatif yang dilakukan melalui uji coba ahli (Expert Review) yang terdiri dari ahli bahasa, ahli materi, ahli media, dan guru kelas IV serta uji coba perorangan (one to one). Evaluasi dilakukan untuk melihat kelayakan media permainan Jenga Edukasi sehingga produk yang dikembangkan dinyatakan bisa digunakan sebagai media aktivitas proses IPA Macammacam Gaya dan Pemanfaatannya di kelas IV.

\section{Pengujian Keefektifan Produk}

Media setelah direalisasikan menjadi sebuah produk terlebih dahulu melewati tahap expert review untuk melihat efektifitas dan ketepatan media untuk digunakan di kelas IV. Peneliti melibatkan dosen Universitas Negeri Jakarta dan guru kelas IV untuk menjadi validator dalam penilaian media permainan Jenga Edukasi. Hasil dari keseluruhan validator apabila memberikan saran dan masukan maka peneliti akan memberikan perbaikan demi penyempurnaan produk. Berikut peneliti rangkum hasil expert review.

Tabel 3. Rekapitulasi Hasil Uji Coba Ahli Bahasa

\begin{tabular}{|c|c|c|c|c|}
\hline Aspek & $\begin{array}{l}\text { Nomor } \\
\text { Kuisioner }\end{array}$ & Nilai & $\begin{array}{c}\text { Jumlah } \\
\text { Per-aspek }\end{array}$ & $\begin{array}{c}\text { Jumlah } \\
\text { Maksimum }\end{array}$ \\
\hline \multirow[t]{3}{*}{ Keterbacaan. } & 1 & 4 & \multirow{3}{*}{11} & \multirow{3}{*}{12} \\
\hline & 2 & 4 & & \\
\hline & 3 & 3 & & \\
\hline \multirow{3}{*}{$\begin{array}{l}\text { Kesesuaian dengan kaidah } \\
\text { Bahasa Indonesia. }\end{array}$} & 4 & 4 & \multirow{3}{*}{16} & \multirow{3}{*}{16} \\
\hline & 5 & 4 & & \\
\hline & 6 & 4 & & \\
\hline
\end{tabular}




\begin{tabular}{|c|c|c|c|c|}
\hline & 7 & 4 & & \\
\hline \multirow{2}{*}{$\begin{array}{l}\text { Kesesuaian bahasa dengan } \\
\text { peserta didik }\end{array}$} & 8 & 4 & \multirow{2}{*}{12} & \multirow{2}{*}{12} \\
\cline { 2 - 3 } & 9 & 4 & & \\
\cline { 2 - 3 } & 10 & 4 & $\mathbf{4 0}$ \\
\hline Total & $\mathbf{1 0}$ & $\mathbf{3 9}$ & $\mathbf{3 9}$ & $\mathbf{9 7 , 5 \%}$ \\
\hline Persentase & \multicolumn{3}{|l}{} & \\
\hline
\end{tabular}

Hasil penilaian oleh ahli bahasa terhadap media permainan Jenga Edukasi mendapatkan nilai sebesar 97,5\% dan termasuk kategori Sangat Baik.

Tabel 4. Rekapitulasi Hasil Uji Coba Ahli Materi

\begin{tabular}{|c|c|c|c|c|}
\hline Aspek & $\begin{array}{c}\text { Nomor } \\
\text { Kuisioner }\end{array}$ & Nilai & $\begin{array}{c}\text { Jumlah } \\
\text { Per-aspek }\end{array}$ & $\begin{array}{c}\text { Jumlah } \\
\text { Maksimum }\end{array}$ \\
\hline \multirow{4}{*}{$\begin{array}{l}\text { Kesesuaian dengan } \\
\text { kompetensi. }\end{array}$} & 1 & 4 & \multirow{4}{*}{16} & \multirow{4}{*}{16} \\
\hline & 2 & 4 & & \\
\hline & 3 & 4 & & \\
\hline & 4 & 4 & & \\
\hline \multirow[t]{4}{*}{ Penyajian materi. } & 5 & 4 & \multirow{4}{*}{16} & \multirow{4}{*}{16} \\
\hline & 6 & 4 & & \\
\hline & 7 & 4 & & \\
\hline & 8 & 4 & & \\
\hline \multirow{2}{*}{$\begin{array}{l}\text { Ketepatan penggunaan } \\
\text { media. }\end{array}$} & 9 & 4 & \multirow{2}{*}{8} & \multirow{2}{*}{8} \\
\hline & 10 & 4 & & \\
\hline Total & 10 & 40 & \multirow[t]{2}{*}{40} & 40 \\
\hline Persentase & & & & $100 \%$ \\
\hline
\end{tabular}

Hasil penilaian oleh ahli materi terhadap media permainan Jenga Edukasi mendapatkan nilai sebesar 100\% dan termasuk kategori Sangat Baik.

Tabel 5. Rekapitulasi Hasil Uji Coba Ahli Media

\begin{tabular}{|c|c|c|c|c|}
\hline Aspek & $\begin{array}{c}\text { Nomor } \\
\text { Kuisioner }\end{array}$ & Nilai & $\begin{array}{c}\text { Jumlah } \\
\text { Per-aspek }\end{array}$ & $\begin{array}{c}\text { Jumlah } \\
\text { Maksimum }\end{array}$ \\
\hline \multirow[t]{3}{*}{ Komponen isi media. } & 1 & 3 & \multirow{3}{*}{10} & \multirow{3}{*}{12} \\
\hline & 2 & 3 & & \\
\hline & 3 & 4 & & \\
\hline \multirow[t]{4}{*}{ Desain media. } & 4 & 4 & \multirow{4}{*}{32} & \multirow{4}{*}{32} \\
\hline & 5 & 4 & & \\
\hline & 6 & 4 & & \\
\hline & 7 & 4 & & \\
\hline
\end{tabular}




\begin{tabular}{|c|c|c|c|c|}
\hline & 8 & 4 & & \\
\hline & 9 & 4 & & \\
\hline & 10 & 4 & & \\
\hline & 11 & 4 & & \\
\hline \multirow[t]{4}{*}{ Penggunaan media. } & 12 & 4 & \multirow{4}{*}{15} & \multirow{4}{*}{16} \\
\hline & 13 & 3 & & \\
\hline & 14 & 4 & & \\
\hline & 15 & 4 & & \\
\hline Total & 15 & 57 & 57 & 60 \\
\hline Persentase & & & & $95 \%$ \\
\hline
\end{tabular}

Hasil penilaian oleh ahli media terhadap media permainan Jenga Edukasi mendapatkan nilai sebesar 95\% dan termasuk kategori Sangat Baik.

Tabel 6. Rekapitulasi Hasil Uji Coba Ahli Media

\begin{tabular}{|c|c|c|c|c|}
\hline Aspek & $\begin{array}{c}\text { Nomor } \\
\text { Kuisioner }\end{array}$ & Nilai & $\begin{array}{c}\text { Jumlah } \\
\text { Per-aspek }\end{array}$ & $\begin{array}{c}\text { Jumlah } \\
\text { Maksimum }\end{array}$ \\
\hline \multirow{2}{*}{$\begin{array}{l}\text { Kesesuaian } \quad \text { dengan } \\
\text { kompetensi. }\end{array}$} & 1 & 4 & \multirow{2}{*}{8} & \multirow{2}{*}{8} \\
\hline & 2 & 4 & & \\
\hline \multirow[t]{3}{*}{ Penyajian materi. } & 3 & 3 & \multirow{3}{*}{11} & \multirow{3}{*}{12} \\
\hline & 4 & 4 & & \\
\hline & 5 & 4 & & \\
\hline \multirow[t]{5}{*}{ Desain media. } & 6 & 4 & \multirow{5}{*}{20} & \multirow{5}{*}{20} \\
\hline & 7 & 4 & & \\
\hline & 8 & 4 & & \\
\hline & 9 & 4 & & \\
\hline & 10 & 4 & & \\
\hline \multirow[t]{5}{*}{ Penggunaan media. } & 11 & 3 & \multirow{5}{*}{19} & \multirow{5}{*}{20} \\
\hline & 12 & 4 & & \\
\hline & 13 & 4 & & \\
\hline & 14 & 4 & & \\
\hline & 15 & 4 & & \\
\hline Total & 15 & 57 & 58 & 60 \\
\hline Persentase & & & & $96,7 \%$ \\
\hline
\end{tabular}

Hasil penilaian oleh guru kelas IV terhadap media permainan Jenga Edukasi mendapatkan nilai sebesar 96,7\% dan termasuk kategori Sangat Baik. 
Setelah validasi produk oleh ahli, selanjutnya produk media permainan Jenga Edukasi di uji coba kepada peserta didik dengan beberapa tahap yaitu one to one, small group, dan field test. Namun dikarenakan pandemi covid-19 yang sedang melanda Indonesia, maka uji coba diimplementasikan hanya sampai tahap one to one. Penelitian melibatkan lima siswa kelas IV yang dilaksanakan pada Minggu, 30 Mei 2021. Uji coba dilakukan untuk mengetahui keefektifan dan untuk menguji keberhasilan pengembangan media permainan Jenga Edukasi.

Tabel 7. Rekapitulasi Hasil Uji Coba One To One

\begin{tabular}{|c|c|c|c|c|c|c|c|c|}
\hline \multirow{2}{*}{ Aspek } & \multirow{2}{*}{$\begin{array}{c}\text { Nomor } \\
\text { Kuisioner }\end{array}$} & \multicolumn{5}{|c|}{ Responden } & \multirow{2}{*}{ Jumlah } & \multirow{2}{*}{ Persentase } \\
\hline & & 1 & 2 & 3 & 4 & 5 & & \\
\hline \multirow{2}{*}{$\begin{array}{l}\text { Desain } \\
\text { tampilan media. }\end{array}$} & 1 & 1 & 1 & 1 & 1 & 1 & 5 & $100 \%$ \\
\hline & 2 & 1 & 1 & 1 & 1 & 1 & 5 & $100 \%$ \\
\hline \multirow{6}{*}{$\begin{array}{l}\text { Pengoperasian } \\
\text { media. }\end{array}$} & 3 & 1 & 1 & 1 & 0 & 1 & 4 & $80 \%$ \\
\hline & 4 & 1 & 1 & 1 & 1 & 1 & 5 & $100 \%$ \\
\hline & 5 & 1 & 1 & 1 & 1 & 1 & 5 & $100 \%$ \\
\hline & 6 & 1 & 1 & 1 & 1 & 1 & 5 & $100 \%$ \\
\hline & 7 & 1 & 1 & 1 & 1 & 1 & 5 & $100 \%$ \\
\hline & 8 & 1 & 1 & 1 & 1 & 0 & 4 & $80 \%$ \\
\hline \multirow[t]{2}{*}{ Ketertarikan. } & 9 & 1 & 1 & 1 & 1 & 1 & 5 & $100 \%$ \\
\hline & 10 & 1 & 1 & 1 & 1 & 0 & 4 & $80 \%$ \\
\hline Total & 10 & 10 & 10 & 10 & 9 & 8 & 47 & $94 \%$ \\
\hline
\end{tabular}

Hasil rekapitulasi perhitungan uji coba one to one terhadap lima siswa kelas IV, media permainan Jenga Edukasi mendapatkan nilai sebesar 94\% dan termasuk kategori Sangat Baik.

\section{KESIMPULAN}

Pengujian keefektifan produk oleh ahli memperoleh penilaian yang beragam. Pada tahap uji ahli bahasa, media permainan Jenga Edukasi memperoleh 97,5\% termasuk dalam kategori Sangat Baik. Pada tahap uji ahli materi, media permainan Jenga Edukasi memperoleh 100\% termasuk dalam kategori Sangat Baik. Pada tahap uji ahli media, media permainan Jenga Edukasi memperoleh 95\% dengan kategori Sangat Baik. Serta melibatkan satu guru kelas yang memvalidasi media permainan Jenga Edukasi dan menghasilkan 96,7\% termasuk dalam kategori Sangat Baik. Akumulasi keseluruhan penilaian, maka media permainan Jenga Edukasi memperoleh penilaian akhir yaitu 97,3\% dan termasuk dalam kategori Sangat Baik dengan rentang penilaian 76\%-100\% setelah media melalui proses perbaikan dan penyempurnaan melalui saran dan masukan dari validator. 
Implementasi media permainan Jenga Edukasi dilakukan melalui tahap uji coba perorangan (one to one) dengan melibatkan lima peserta didik kelas IV SD. Berdasarkan hasil uji coba tersebut, permainan Jenga Edukasi memperoleh $94 \%$ sehingga dikategorikan sebagai Sangat Baik.

Berdasarkan hasil uji coba tersebut media permainan Jenga Edukasi dalam aktivitas proses pembelajaran IPA membuat peserta didik aktif dan termotivasi untuk belajar dikarenakan media berupa permainan yang dapat dilakukan sambil bermain dengan tampilan media yang menarik membuat peserta didik menyukai dan dapat memahami serta merekonstruksi pemahaman mereka dengan sekitar mengenai macam-macam gaya dan pemanfaatannya dengan baik.

Kesimpulan yang diperoleh dari penelitian pengembangan ini yaitu media permainan Jenga Edukasi sangat layak untuk digunakan berdasarkan hasil rata-rata dari expert review menghasilkan produk dengan kategori Sangat Baik yaitu 97,3\% serta media Jenga Edukasi mendapat kategori Sangat Baik yaitu 94\% oleh peserta didik kelas IV SD yang dilakukan uji coba terhadap media permainan Jenga Edukasi ini sehingga membuat peserta didik kelas IV SD semangat dan termotivasi pada saat pembelajaran. Penilaian tersebut berada pada kategori Sangat Baik dengan rentang 76\%-100\% sehingga dapat dinyatakan bahwa media permainan Jenga Edukasi layak digunakan pada pembelajaran IPA materi Macam-macam Gaya dan Pemanfaatannya kelas IV Sekolah Dasar.

Secara umum pengembangan media ini dapat dijadikan referensi dalam melakukan penelitian sejenis atau pengembangan media yang telah dikembangkan secara lebih mendalam agar pembuatan media lebih baik. Pengembangan media ini diharapkan mampu menjadi motivasi dalam mengembangkan media pembelajaran kreatif dan efektif. Penelitian pengembangan ini peneliti tidak melakukan uji coba small group dan field test, oleh sebab itu peneliti merekomendasikan bagi peneliti selanjutnya untuk melakukan uji coba lebih lengkap dengan jumlah peserta didik lebih banyak demi mengetahui peningkatan hasil belajar peserta didik.

\section{DAFTAR PUSTAKA}

Adnan, Evita dkk. 2016. Perkembangan Peserta Didik. Jakarta: Universitas Negeri Jakarta. Ahmad, Arifin. 2017. Penerapan Permainan Bahasa (Katarsis) Untuk Meningkatkan Keterampilan Membaca Siswa Kelas IV A SD Negeri 01 Metro Pusat. Jurnal Pendidikan Dasar, Vol.9 No.2 Hal. 77.

Ariyanto, Metta. 2016. Peningkatan Hasil Belajar IPA materi Kenampakan Rupa Bumi Menggunakan Model Scramble. Jurnal Profesi Pendidikan Dasar, Vol.3 No.2 Hal. 134.

Burhein, Erick. 2017. Aktivitas Fisik Olahraga Untuk Pertumbuhan dan Perkembangan Siswa SD. Journal of Primary Education, Vol.1 No.1 Hal.52. 
Fransiska, Della Putri dkk. 2020. Analisis Penerapan Model Teams Games Tournament Disertai Media Permainan Jenga Pada Materi Volume Bangun Ruang Kelas V SDN Patihan Kota Madiun. Jurnal Prosiding Konferensi Ilmiah Dasar, Vol.2 Hal.159.

Hamid, Mustofa Abi dkk. 2020. Media Pembelajaran. Jakarta: Yayasan Kita Menulis. Pribadi, Benny A. 2017. Media dan Teknologi dalam Pembelajaran. Jakarta: Kencana.

Tegeh, I Made dan I Made Kirna. 2013. Pengembangan Bahan Ajar Model Penelitian Pendidikan dengan ADDIE Model. Jurnal IKA, Vol.11 No.1 Hal. 13.

Undang-undang No. 20. 2003. Sistem Pendidikan Nasional. Bab I, Pasal 1 ayat (1) no. 1.

Zainiyati, Husniyatus Salamah. 2017. Pengembangan Media Pembelajaran Agama Islam Berbasis ICT. Jakarta: Kharisma Putra Utama. 